\title{
PEMBERDAYAAN DIFABEL DALAM PELAKSANAAN PROGRAM KELOMPOK USAHA BERSAMA (KUBE) DI DESA SURUH, KECAMATAN TASIKMADU, KABUPATEN KARANGANYAR
}

\author{
EMPOWERMENT DISABILITIES IN THE IMPLEMENTATION OF \\ THE PROGRAM JOINT BUSINESS GROUP (KUBE) IN THE VILLAGE \\ SURUH TASIKMADU DISTRICT, DISTRICT KARANGANYAR
}

\author{
Hendra Wijayanto \\ Dosen Program Studi Administrasi Publik \\ Fakultas Ilmu Sosial dan Ilmu Politik \\ Universitas 17 Agustus 1945 Jakarta \\ hendra.pelajar@gmail.com
}

\begin{abstract}
ABSTRAK
Penyandang cacat merupakan bagian dari Indonesia, namun keberadaan mereka dalam kehidupan masih terpinggirkan. Cacat memiliki hak yang sama, kewajiban dan peran yang sama dengan warga negara lainnya. Kesempatan untuk mendapatkan kesetaraan, hak dan kewajiban bagi penyandang cacat. Masalah dengan cacat timbul karena gangguan dalam kegiatan sosial menghambat fisik mereka, sehingga mengurangi hak-hak ekonomi dan politik penyandang cacat untuk mencapai kesejahteraan. Penelitian ini merupakan deskriptif kualitatif. Teknik penentuan informan dilakukan secara purposive. Pengumpulan data yang digunakan adalah wawancara, observasi langsung dan review dokumen. Validitas data menggunakan teknik triangulasi sumber. Data dianalisis menggunakan model interaktif. Memberdayakan penyandang cacat melalui Kelompok Usaha Bersama (KUBE) di Desa Katakan, Kecamatan Tasikmadu, Karanganyar termasuk pemberdayaan yang mental, fisik, dan keterampilan sosial dengan memberikan keterampilan memasak, menjahit, bengkel atau mekanik, video yang elektro audio dan teknik memijat. Cacat pemberdayaan dalam upaya meningkatkan kesejahteraan sosial tidak dapat dipisahkan dari peran pendampingan dan penguatan peran cacat potensial. Tidak hanya itu, pemberdayaan penyandang cacat juga dihadapkan dengan sejumlah kendala seperti pola perilaku, masalah kerja dan dampak ekonomi, sosial, dan psikologis pada sejumlah aspek saja dari segi psikologis, dan ekonomi cacat aksesibilitas.
\end{abstract}

Kata kunci : Pemberdayaan, Masyarakat, Disability, Birokrasi. 


\begin{abstract}
People with disabilities are part of Indonesia, but their existence in life are still marginalized. Disabilities have the same rights, obligations and the same role with the citizens of other countries. The opportunity to gain equality, rights and obligations for the disabled. Problems with disabilities arise because of the disruption in their physical hamper social activities, thus reducing the economic and political rights of the disabled to prosper. The research is a qualitative descriptive. Technique of determining informant done purposively. The collection of data used were interviews, direct observation and review of documents. The validity of the source data using triangulation techniques. Data were analyzed using an interactive model. Empowering the disabled through Joint Business Group (KUBE) in the village of Tell, District Tasikmadu, Karanganyar include empowerment that is mental, physical, and social skills by providing cooking skills, sewing, workshop or mechanic, electro audio video and massaging techniques. Empowerment disabilities in efforts to improve social welfare can not be separated from the role of mentoring and strengthening the role of potential disabilities. Not only that, the empowerment of the disabled are also faced with a number of constraints such as a pattern of behavior, work problems and economic, social, and psychological impact on a number of aspects of the course in terms of both psychological, and economic Accessibility disabilities.
\end{abstract}

\title{
Keywords : Empowerment, Community, Disability, Bureaucracy
}

\section{PENDAHULUAN}

Difabel merupakan bagian dari masyarakat Indonesia, akan tetapi keberadaan mereka dalam kehidupan sehari-hari masih terpinggirkan. Masyarakat cenderung membelaskasihani daripada memberikan kesempatan pada kaum difbel untuk bersemangat mandiri. Mereka dianggap golongan yang lemah sehingga menyebabkan sebagian dari mereka kurang percaya diri, terisolir, minder dari masyarakat. Padahal selayakna manusia normal, mereka juga ingin diakui keberadaanya dan diperlakukan secara wajar serta ingin mendapatkan kebahagian.
Penyandang cacat sebagai warga Negara Indonesia mempunyai hak, kewajiban dan peran yang sama dengan warga Negara lainnya. Hal ini dijamin dalam UUD 1945 pasal $28 \mathrm{C}$ ayat 1 bahwa setiap orang berhak mengembangkan diri melalui pemenuhan kebutuhan dasarnya, berhak mendapat pendidikan, memperoleh manfaat dari ilmu pengetahuan dan teknologi serta seni dan budaya demi meningkatkan kualitas hidupnya dan kesejahteraan umat. Dalam pasal 31 ayat 1 disebutkan bahwa setiap warga Negara berhak mendapatkan pendidikan serta di Undang-Undang No 2 Tahun 1989 tentang Sistem pendidikan Nasional pasal 8 ayat 1 Page | 139 
bahwa warga Negara yang memiliki kelainan fisik dan mental berhak mendapatkan pendidikan luar biasa. Difabel juga kehilangan hak untuk memperoleh kesempatan kerja, padahal telah dijamin dalam UUD 1945 pasal 27 ayat 2 dimana tiap-tiap warga Negara berhak atas pekerjaan dan penghidupan yang layak bagi kemanusiaan.

Oleh karena itu, dalam pelaksanaan suatu kebijakan pemerintah perlu dicegah adanya diskriminasi yang merugikan para difabel, kaum muda, mereka yang berusiaa lanjut untuk memperoleh dan memiliki pekerjaan yang produktif yang memberikan imbalan yang layak. Difabel memiliki harkat dan martabat yang sama dengan manusia yang tidak cacar. Apalagi dalam UUD 1945 pasal 28 ayat 1 dan 2 menyatakan bahwa "Setiap orang berhak mendapatkan perlindungan terhadap perlakuan yang bersifat diskriminasi apapun atas dasar apapun dan berhak mendapat perlindungan terhadap perlakuan yang bersifat diskriminatif itu".

Kesempatan untuk mendapat kesamaan kedudukan, hak dan kewajiban bagi difabel dapat diwujudkan jika tersedia aksesabilitas yaitu suatu kemudahan bagi difabel untuk mencapai kesamaan baik dalam memperoleh pendidikan maupun pekerjaan. Sehingga tercipta kesejahteraan sosial. Kesejahteraan sosial menurut
UU No 4 Tahun 1997 tentang Penyandang Cacat adalah "Suatu tata kehidupan dan penghidupan sosial material maupun spiritual yang diliputi oleh rasa keselamatan, kesusilaan dan ketentraman lahir dan batin yang memungkinkan bagi seorang warga Negara untuk mengadakan usaha pemenuhan kebutuhan jasmaniah, rohaniah dan sosial yang sebaik-baiknya bagi diri, keluarga serta masyarakat yang menjunjung tinggi hak dan kewajiban warga Negara sesuai dengan Pancasila”.

Indonesia dalam melakukan pembangunan nasional mencakup berbagai bidang, salah satunya adalah pembangunan kesejahteraan sosial. Pembangunan kesejahteraan sosial dilakukan secara terencana dan terarah, melalui berbagai bentuk intervensi, pelayanan sosial untuk memenuhi kebutuhan manusia, mencegah dan mengatasi sosial serta memperkuat istitusi sosial (Edy Suharto, 2004:97). Sasaran pembangunan kesejahteraan sosial mencakup seluruh masyarakat, temasuk masyarakat yang menyandang masalah kesejahteraan sosial yaitu orang yang berstatus penyandang cacat (Depsos RI, 1996:17)

Pemberdayaan difabel yang dilakukan di Indonesia dewasa ini, tidak terlepas dari adanya strategi pembangunan sosial kawasan ESCAP (Komisi Sosial Ekonomi 
bagi Kawasan Asia Pasifik) di Manila. Strategi ini diarahkan untuk meningkatkan mutu kehidupan seluruh warga masyarakat mulai dari pengentasan kemiskinan, realisasi keadailan yang merata dan peningkatan partisipasi masyarakat khususnya partisipasi warga difabel di kawasan Asia Pasifik. Dengan ditetapkan agenda aksi untuk difabel maka segenap pemerintah di kawasan Asia Pasifik telah berkomitmen untuk terwujudnya peran serta penuh warga difabel.

Peran pemerintah daerah sangat sentral dilihat dari sisi aksesabilitas fisik maupun non fisik penyandang cacat. Kondisi riil para penyandang cacat selama ini dinilai belum mendapat kesempatan yang setara dengan masysrakat umum lainnya. Bahkan umumnya masih meragukan kemampuan para difabel dalam berbagai aktivitas kehidupan, hal tersebut ditunjukkan ketikaa para penyandang cacat hendak melanjutkan pendidikan di sekolahsekolah umu seringkali mendapatkan tanggapan negatif.

Permasalahan difabel timbul karena adanya gangguan pada fisik mereka yang menghambat aktivitasaktivitas sosial, ekonomi maupun politik sehingga mengurangi hak difabel. Untuk memecahkan permasalahan tersebut diperlukan dua pendekatan dasar yaitu memberdayakan mereka melalui usaha-usaha rehabilitas pendidikan, bantuan usaha dan sebagainya. Sehingga difabel dapat meningkatkan kemampuan dan keterampilannya sebagai modal dasar dan difabel tidak lagi sebagai obyek, tetapi dijadikan sebagai subyek dalam pembangunan.

Sebagai wujud dari upaya terhadap peningkatan kesejahteraan sosial difabel, maka pemerintah melakukan kegiatan pemberdayaan melalui program Kelompok Usaha Bersama (KUBE). Kabupaten Karanganyar merupakan salah satu wilayah yang melakukan pemberdayaan difabel melalui program KUBE tersebut. KUBE adalah kelompok warga atau keluarga binaan sosial yang dibentuk oleh warga melalui proses kegiatan Program Kesejahteraan Sosial (PROKESOS) untuk melaksanakan kegiatan kesejahteraan sosial dan usaha ekonomi dan sebagai sarana untuk meningkatkan taraf kesejahteraan sosialnya.

Program KUBE merupakan salah satu strategi Departemen Sosial untuk memberdayakan difabel, dilakukan dengan pemberian modal usaha, pelatihan usaha, peningkatan keterampilan, bimbingan motivasi usaha dan pendampingan kepada penyandang cacat, meliputi bisu tuli, tuna netra, bibir sumbing, cacat fisik keterlambatan mental tanpa memandang perbedaan suku, agama dan asala usul penyandang. Penelitian ini berusaha untuk 
menganalisis proses pelaksanaan program Kelompok Usaha Bersama (KUBE) dalam memberdayakan difabel sebagai upaya meningkatkan kesejahteraan sosial di Desa Suruh, Kecamatan Tasikmadu, Kabupaten Karanganyar.

\section{KAJIAN PUSTAKA}

\section{Teori Aksi}

Dalam teori aksi ini aktor mengejar tujuan dalam situasi dimana norma-norma mengarahkan dalam memilih alternatif cara dan alat untuk mencapai tujuan. Norma-norma itu tidak menerapkan pilihannya terhadap cara atau alat, tetapi ditentukan oleh aktor untuk memilih. Kemampuan memilih inilah yang disebut Parsons sebagai Voluntarism.Voluntarism adalah kemampuan individu untuk menetapkan alat atau cara dari sejumlah alternatif yang tersedia dalam rangka mencapai tujuan.

Jika dipandang dengan menggunakan teori aksi tersebut disini difabel adalah sebagai aktor yang memburu suatu tujuan yaitu bertujuan untuk memberdayakan difabel. Cara atau alat tersebut diimplementasikan dalam program Kelompok Usaha Bersama (KUBE) dalam upaya peningkatan kesejahteraan sosial

\section{Strategi Pemberdayaan}

\section{a. Definisi Pemberdayaan}

$\begin{array}{lr}\text { Secara } & \text { Konseptual } \\ \text { pemberdayaan } & \text { atau } \\ \text { empowerment berasal dari kata } \\ \text { power } \quad \text { (kekuasaan atau }\end{array}$
keberdayaan). Pemberdayaan menunjuk pada kemampuan orang, khususnya kelompok rentan dan lemah sehingga mereka memiliki kekuatan atau kemampuan dalam memenuhi kebutuhan dasarnya sehingga mereka memiliki kebebasan, dalam arti bukan saja bebas mengemukakan pendapat, melainkan bebas dari kelaparan, bebas dari kebodohan dan bebas dari kesakitan. Menjangkau sumber-sumber produktif yang memungkinkan mereka dapat meningkatkan pendapatannya dan memperoleh barang dan jasa-jasa yang mereka perlukan; dan berpartisipasi dalam proses pembangunan dan keputusan-keputusan yang mempengaruhi mereka (Suharto, 2004).

Beberapa ahli dibawah ini mengungkapkan definisi pemberdayaan dilihat dari tujuan, proses, dan cara-cara pemberdayaan :

a. Pemberdayaan bertujuan untuk meningkatkan kekuasaan orang-orang yang lemah dan tidak beruntung (Ife, 1995). 
b. Pemberdayaan adalah sebuah proses dengan mana orang menjadi cukup kuat untuk berpartisipasi dalam berbagai pengontrolan atas dan mempengaruhi terhadap kejadiankejadian serta lembagalembaga yang mempengaruhi

kehidupannya.

Pemberdayaan menekankan bahwa orang memperoleh keterampilan, pengetahuan, dan kekuasaan yang cukup untuk mempengaruhi kehidupannya dan kehidupan orang lain yang menjadi perhatiannya (Parsons, 1994).

c. Pemberdayaan

menunjukkan pada usaha pengalokasian kembali kekuasaan melalui pengubahan struktur sosial (Swift dan Levin, 1987).

(dalam Suharto, 2004)

Block (1987) describes empowerment as "a state of mind as well as a result of positions, policies, and practices." (p. 65) one has to read an entire chapter to understand what he means when he says, "to feel empowerment means several things. We feel our survival is in our own hands... we have an underlying purpose... we commit ourselves to achieving that purpose, now,"(block, 1987,p. 65).

\section{Block}

memaparkan pemberdayaan sebagai "suatu cara pandang seperti halnya hasil suatu keadaan, kebijakan, dan tindakan." (hlm.65). seseorang harus menbaca seluruh bab yang ditulis Block untuk dapat memahami maksud dari ucapannya berupa: "Untuk merasakan memberikan wewenang artinya ada pada beberapa hal. Kita merasa bahwa kelangsungan hidup kita ada di tangan kita sendiri... kita mempunyai suatu dasar tujuan... Kini, kita berkomitmen untuk meraih tujuan itu." (Block, 1987:65).

Kegiatan

pemberdayaan dapat mengacu pada banyak kegiatan, diantaranya meningkatkan kesadaran akan adanya kekuatan-kekuatan sosial yang menekan orang lain dan juga pada aksi-aksi untuk mengubah pola kekuasaan di masyarakat. Menurut Kartasasmita pemberdayaan harus dilakukan melalui tiga cara, yaitu : 
a. Menciptakan suasana atau iklim yang memungkinkan potensi individu dapat berkembang.

b. Memperkuat potensi atau daya yang dimiliki oleh rakyat dengan menerapkan langkahlangkah nyata, menampung berbagai masukan, menyediakan sarana dan prasarana baik fisik maupun sosial yang dapat diakses oleh masyarakat lapisan paling bawah.

c. Memberdayakan rakyat dalam arti melindungi dan membela kepentingan masyarakat lemah. Dalam pemberdayaan harus dicegah jangan sampai yang lemah menjadi semakin lemah atau terpinggirkan dalam menghadapi yang kuat. (Kartasasmita, 1996:19)

\section{b. Prinsip Pemberdayaan}

$$
\begin{aligned}
& \text { Prinsip tersebut adalah } \\
& \text { landasan dasar yang harus } \\
& \text { dimiliki oleh seorang pekerja } \\
& \text { sosial, masyarakat, dan harus } \\
& \text { terinternalisasi dalam diri } \\
& \text { pekerja sosial yang bergerak } \\
& \text { dalam konteks masyarakat. } \\
& \begin{array}{l}
\text { Beberapa prinsip } \\
\text { pemberdayaan menurut Kiefer }
\end{array}
\end{aligned}
$$

(1981) pemberdayaan mencakup tiga dimensi yang meliputi: kompetensi kerakyatan, kemampuan sosiopolitik, dan kompetensi partisipasif (dalam Soeharto, 2005: 215).

Parsons (1994) juga mengajukan tiga dimensi pemberdayaan yang merujuk pada:

a. Sebuah proses pembangunan yang bermula dari pertumbuhan individual yang kemudian berkembang menjadi sebuah perubahan sosial yang lebih besar.

b. Sebuah keadaan psikologis yang ditandai oleh rasa percaya diri, berguna dan mampu mengendalikan diri orang lain.

c. Pembebasan yang dihasilkan dari sebuah gerakan sosial, yang dimulai dari pendidikan dan politisasi orangorang lemah dan kemudian melibatkan upayaupaya kolektif dari orang-orang lemah tersebut untuk memperoleh kekuasaan dan mengubah strukturstruktur yang masih 
menekan. (Parsons, et.al., 1994 :106).

\section{c. Strategi Pemberdayaan}

Dalam konteks pekerjaan sosial pemberdayaan dapat dilakukan melalui tiga asas pemberdayaan (empowerment setting): mikro, mezzo, makro.

a. Asas Mikro.

Pemberdayaan dilakukan terhadap klien secara individu melalui bimbingan, konseling, stress management, crisis intervention. Tujuan utamanya adalah membimbing atau melatih klien dalam menjalankan tugas-tugas kehidupannya. Model ini sering disebut sebagai pendekatan yang berpusat pada tugas (task centered appproach).

b. Asas Mezzo.

Pemberdayaan dilakukan terhadap sekelompok klien. Pemberdayaan dilakukan dengan menggunakan kelompok sebagai media intervensi. Pendidikan dan pelatihan, dinamika kelompok biasanya dilakukan sebagai strategi dalam meningkatkan kesadaran, pengetahuan keterampilan dan sikap-sikap klien agar memiliki kemampuan

memecahkan masalah yang dihadapinya.

c. Asas Makro.

Pendekatan ini disebut juga strategi sistem besar (large- system strategy), karena sasaran perubahan diarahkan pada sistem lingkungan yang lebih luas. Perumusan kebijaksanaan, perencanaan sosial, kampanye, aksi sosial, lowbbying, pengorganisasian masyarakat, manajemen konflik, adalah beberapa strategi dalam pendekatan ini. Strategi sistem besar memandang klien sebagai orang yang memiliki kompetensi untuk memahami situasi mereka sendiri dan untuk memilih serta menentukan strategi yang tepat untuk bertindak (Suharto, 2004:66-67).

\section{Difabel}

\section{a. Pengertian Difabel}

$$
\begin{aligned}
& \text { Difabel biasa disebut } \\
& \text { cacat. Kecacatan adalah } \\
& \text { kerusakan kemampuan untuk } \\
& \text { kehidupan dan pekerjaan } \\
& \text { yang disebabkan oleh luka } \\
& \text { penyakit atau cacat sejak lahir } \\
& \text { (Suparlan, 1984:53). Dari } \\
& \text { definisi tersebut dapat }
\end{aligned}
$$


disimpulkan bahwa kecacatan

tidak menyangkut hal mengenai kehilangan kemampuan tetapi lebih bersifat kerusakan kemampuan sebagai akibat dari kerusakan fungsi alat tubuh yang menyebabkan kesulitan dalam beraktifitas seperti manusia normal, sehingga jika diberi upaya penanganan khusus sesuai dengan jenis kecacatannya maka kemampuan beraktifitas tersebut dapat ditingkatkan.

Menurut UndangUndang No. 25 tahun 1997 Tentang Jaminan Sosial Tenaga Kerja: "Cacat adalah keadaan hilanganya atau berkurangnya fungsi anggota badan secara langsung atau tidak langsung mengakibatkan hilang atau berkurangnya kemampuan untuk menjalankan pekerjaan." Adapun yang dimaksud dengan penyandang cacat berdasarkan Peraturan Pemerintah No.43 tahun 1998 diartikan sebagai berikut:

"Penyandang cacat adalah setiap orang yang mempunyai kelainan fisik dan atau mental, yang dapat mengganggu atau merupakan rintangan dan hambatan baginya untuk melakukan kegiatan

secara selayaknya."

Berdasarkan UndangUndang No 4 tahun 1997 tentang Penyandang cacat bahwa Sedangkan macam kecacatan terdiri dari:

1. Cacat fisik adalah kecacatan yang mengakibatkan gangguan pada fungsi tubuh, antara lain gerak tubuh, penglihatan, pendengaran, dan kemampuan berbicara.

2. Cacat mental adalah kelainan mental dan atau tingkah laku, baik cacat bawaan maupun akibat dari penyakit, antara lain: a) retardasi mental, b) gangguan psikiatrik fungsional, c) alkoholisme, d) gangguan mental organik dan epilepsi.

3. Cacat fisik dan mental adalah kedaan seseorang yang menyandang dua jenis kecacatan sekaligus. Apabila yang cacat adalah keduanya maka sangat menggangu penyandang cacatnya.

$$
\text { Ada banyak }
$$

terminology yang digunakan sebagai julukan atas keberadaan seseorang yang mengalami kecacatan baik cacat fisik maupun mental 
antara lain seperti penderita cacat, penyandang cacat, orang yang berkelainan, anak luar biasa, invalid dan sebagainya. Belum lama ini kenalkan istilah difabel yang dirasa lebih memiliki keadilan dan memiliki nilainilai kesetaraan di berbagai kalangan masyarakat. Terminologi difabel adalah akronim dari people with different ability dan kemudian digunakan sebagai istilah pengganti penyandang cacat. Istilah penyandang cacat dan beberapa istilah lain yang disebutkan diatas, dinilai mengandung arti diskriminasi dan memiliki kecenderungan sebagai alasan oembenar pada stigma dan streotype atas keberadaan difabel dalam masyarakat. (Demartoto, 2005:11).

$\begin{array}{rr}\text { Penyandang } & \text { cacat } \\ \text { dalam prespektif ideologi }\end{array}$ kenormalan. Ideologi (ajaran) kenormalan menyatakan bahwa seseorang disebut normal adalah bila mempunyai organ tubuh lengkap dan berfungsi dengan baik, harus mempunyai kepala, kaki/ tangan dan organ lain layaknya seorang manusia. Kaki dapat digunakan untuk berlari, tangan untuk memegang atau menulis, mata untuk melihat, mulut untuk berbicara, telinga untuk mendengar dan lain sebagainya. Seseorang yang mengalami ketidakgengsian, kehilangan salah satu atau lebih organ yang dimilikinya, maka orang tersebut tidak sempurna atau istilah yang sering digunakan selama ini adalah cacat.

\section{b. Pengembangan Program Pemberdayaan Berperspektif Difabel Oleh Dinas Sosial.}

Ada dua hal pokok
yang selalu menjadi
pertimbangan
menyusun program dalam
pemberdayaan berprespektif
difabel. Dua hal pokok diri
maupun mereka yang merasa
menjadi manusia normal.
tersebut adalah:

1) Pertama, program yang menekankan pada kepentingan pragmatis untuk menjawab kebutuhan praktis sesaat bagi difabel maupun masyarakat yang sering terlihat dalam rehabilitasi saat ini.

2) Kedua, program yang menekankan pada kepentingan jangka panjang yang menjawab kebutuhan strategis difabel, yaitu memperjuangkan posisi 


dan hak difabel terhadap
ideologi $r$ difabel,
kenormalan
pandangan negatif yang
telah mengakar dalam
keyakinan baik dikalangan
difabel itu sendiri maupun
mereka yang merasa
menjadi manusia normal.

Program

pemberdayaan sudah banyak dikembangkan oleh berbagai lembaga dan ahli yang bekerja dalam bidang rehabilitasi. Berbagai pelayanan rehabilitasi biasanya di kelompokkan dalam empat kategori yaitu:

1) Rehabilitasi Medis, Rehabilitasi medis banyak dilakukan oleh rumah sakit umum, rumah sakit khusus oleh rumah sakit khusus ortopedi dan berbagai jenis klinik.

2) Rehabilitasi Karya $\begin{array}{lr}\text { Rehabilitasi } & \text { karya } \\ \text { menekankan } & \text { pada } \\ \text { vokasional } & \text { training }\end{array}$ untuk persiapan difabel dalam dunia kerja yang banyak dilakukan oleh shelter workshop, loka bina karya dan panti rehabilitasi karya.

3) Rehabilitasi Pendidikan
Rehabilitasi pendidikan dilakukan disekolah untuk anak cacat. Seperti sekolah Luar Biasa (SLB) sekolah dasar luar biasa atau SDLB, dan sekolah terpadu.

4) Rehabilitasi Sosial

$\begin{array}{lr}\text { Rehabilitasi } & \text { sosial } \\ \text { biasanya } & \text { dilakukan } \\ \text { untuk } & \text { membantu } \\ \text { difabel bersosialisasi di } \\ \text { masyarakat. }\end{array}$ Kalau kita cermati, program-program rehabilitasi diatas selalu ditujukan kepada difabel sebagai target group yang dianggap lemah, tidak berdaya dan tidak mandiri. Sedangkan para petugas di rehabilitasi seolah-olah menjadi malaikat-malaikat pemberdaya yang tahu dan mampu memberdayakan difabel. Perlakuan khusus terhadap difabel tersebut menciptakan pengkotakkotakan di kalangan difabel sendiri dan di masyarakat.

Sementara itu banyak sekali ketidakadilan difabel akibat dari stereotype yang disandangkan kepada para difabel. Misalnya saja tanggapan bahwa orang cacat itu tidak mampu, maka banyak perlakuan anggota keluarga atau masyarakat Page | 148 
yang justru menyingkirkan difabel. Bahkan lebih dari itu kekerasan terhadap difabel sering terjadi selain kekerasan fisik seperti pemasungan, pemukulan, pengucilan dengan jalan penyembunyian, pemerkosaan, bentuk-bentuk pelecehan juga sering diterima oleh para difabel. Selain kekerasan fisik juga kekerasan yang dikenakan secara struktural, yaitu segenap peraturan, norma dan nilai di masyarakat dan negara, maupun sarana prasarana yang membuat difabel tidak memiliki akses terhadap sarana dan prasarana tersebut.

Untuk itu, dibutuhkan perubahan paradigma yang lebih mendasar dari isu difabel itu sendiri. Isu difabel yang bersifat individual sehingga pelayanannya berupa perlakuan khusus rehabilitasi bagi difabel harus berubah ke arah isu difabel yang bersifat sosial. Perubahan yang mengarah pada pola perilaku sosial masyarakat secara menyeluruh, tidak hanya difabel. Isu difabel sebagai isu sosial berarti merubah target grup bukan hanya difabel secara eklusif tetapi seluruh anggota masyarakat. Dengan pendekatan pemecahan masalah difabel yang bersifat integratif, terpadu atau inklusif dalam program-program

pembangunan secara menyeluruh (intergrated solution ).

Pembangunan
nasional khususnya
pembangunan sosial tentunya
tidak dapat dilaksanakan oleh
pemerintah sendiri namun
harus dilakukan secara
bersama-sama $\quad$ dengan
masyarakat. Partisipasi
masyarakat merupakan
sumberdaya yang paling
penting dalam tata usaha
kesejahteraan sosial. Tetapi
bagi para difabel partisipasi
dalam masyarakat akan
menjadi suatu hal yang sangat
sulit untuk dilakukan jika
para difabel ini tidak
diberikan suatu penyadaran
tentang potensi yang masih
mereka miliki karena
sebagian besar para difabel
sudah kehilangan semangat
untuk memberdayakan diri
mereka sendiri di dalam
masyarakat.

\section{Kesejahteraan Sosial}

Kesejahteraan sosial
adalah kondisi terpenuhinya
kebutuhan material, spiritual dan
sosial warga negara agar dapat
hidup layak dan mampu
mengembangkan diri, sehingga


dapat melaksanakan fungsi sosialnya (UU No 11 Tahun 2009). Kebijakan sosial adalah salah satu bentuk dari kebijakan publik, dan merupakan ketetapan pemerintah yang dibuat untuk merespon isu-isu yang bersifat publik, seperti mengatasi masalah sosial atau memenuhi kebutuhan masyarakat banyak.

Kesejahteraan sosial adalah keseluruhan usaha sosial yang terorganisir dan mempunyai tujuan utama untuk meningkatkan taraf hidup masyarakat berdasarkan konteks sosialnya. Didalamnya tercakup pula unsur kebijakan dan pelayanan dalam arti luas yang terkait dengan berbagai kehidupan dalam masyarakat, seperti pendapatan, jaminan sosial, kesehatan, perumahan, pendidikan, rekreasi budaya, dan lain sebagainya). (Sulistiati, 2004:25).

Kesejahteraan sosial pada dasarnya juga dapat dipahami dalam dua konteks yang lain, yakni sebagai sebuah institusi (institutions) dan sebagai sebuah displin akademik (academic disipline) (Zastrow, 1989:5). Sebagai institusi kesejahteraan sosial dapat dipahami sebagai program pelayanan maupun pertolongan untuk memenuhi kebutuhan masyarakat. Sedangkan sebagai sebuah disiplin akademik, kesejahteraan sosial mengacu pada suatu studi terhadap lembaga, program maupun kebijakan yang fokus pada pelayanan kepada masyarakat.

\section{Kelompok Usaha Bersama (KUBE)}

KUBE adalah Program Kesejahteraan Sosial (Prokesos) yang diluncurkan Pemerintah RI sejak tahun 1990. KUBE ini dibentuk dengan harapan agar para Penyandang Masalah Kesejahteraan Sosial (PMKS) yang terdapat di Indonesia dapat tereliminir sedikit demi sedikit. Pembentukan KUBE dimulai dengan proses pembentukan kelompok sebagai hasil bimbingan sosial, pelatihan keterampilan berusaha, bantuan stimulans dan pendampingan.

\section{Kelompok}

Usaha Bersama (KUBE) adalah kelompok warga atau keluarga binaan sosial yang dibentuk oleh warga atau keluarga binaan sosial yang telah dibina melalui proses kegiatan PROKESOS untuk melaksanakan kegiatan kesejahteraan sosial dan usaha ekonomi dalam semangat kebersamaan sebagai sarana untuk meningkatkan taraf kesejahteraan sosialnya. Tujuan KUBE diarahkan kepada upaya mempercepat penghapusan kemiskinan, melalui : 
a. Peningkatan kemampuan berusaha para anggota KUBE secara bersama dalam kelompok.

b. Peningkatan pendapatan.

c. Pengembangan usaha.

d. Peningkatan kepedulian dan kesetiakawanan sosial diantara para anggota KUBE dan dengan masyarakat sekitar.

Proses Pembentukan KUBE untuk sasaran PMKS lainnya adalah
a. Pelatihan ketrampilan berusaha, dimaksudkan untuk meningkatkan kemampuan praktis berusaha yang disesuaikan dengan minat dan ketrampilan PMKS serta kondisi wilayah, termasuk kemungkinan pemasaran dan pengembangan hasil usahanya.

b. Pemberian bantuan stimulan sebagai modal kerja atau berusaha yang disesuaikan dengan keterampilan PMKS dan kondisi setempat.

c. Pendampingan, mempunyai peran sangat penting bagi keberhasilan KUBE. Pendampingan dilaksanakan oleh PSK yang dibantu oleh infrastruktur kesejahteraan

$\begin{array}{lrr}\text { sosial di daerah } & \text { seperti } \\ \text { Karang } & \text { Taruna } & \text { (KT), } \\ \text { Pekerja } & \text { Sosial Masyarakat } \\ \text { (PSM), Organisasi } & \text { Sosial } \\ \text { (ORSOS) dan } & \text { Panita } \\ \text { Pemimpin } & \text { Usaha } \\ \text { Kesejahteraan } & \text { Sosial } \\ \text { (WPUKS). } & \end{array}$

Keanggotaan KUBE berasal dari : 1) Anggota KUBE adalah PMKS sebagai sasaran program yang telah disiapkan. Jumlah anggota untuk setiap KUBE berkisar antara 5 sampai 10 orang / KK sesuai dengan jenis PMKS; 2) Khusus untuk Pembinaan Masyarakat Terasing dan Rehabilitasi Sosial Daerah Kumuh pembentukan KUBE berdasarkan unit pemukiman sosial, artinya suatu unit pemukiman sosial adalah satu KUBE. Kegiatan Pembinaan, Monitoring dan Evaluasi dilakukan secara berjenjang baik di tingkat propinsi, kabupaten/kota, kecamatan, kelurahan. Tujuannya untuk mengetahui perkembangan dan hambatan pelaksanaan KUBE. Serta upaya pemecahannya.

\section{METODE PENELITIAN}

\section{Jenis Penelitian}

Penelitian ini merupakan penelitian kualitatif dengan jenis penelitian deskriptif. Dalam penelitian ini bertujuan 
mendeskripsikan pemberdayaan

melalui program KUBE dalam upaya meningkatkan

kesejahteraan sosial bagi difabel

di Desa Suruh, Kecamatan

Tasikmadu,

Kabupaten

Karanganyar.

2. Lokasi Penelitian

Penelitian ini dilakukan di

Desa Suruh, Kecamatan

Tasikmadu, Kabupaten

Karanganyar. Hal ini dikarenakan terdapat difabel yang membentuk KUBE.

3. Sumber Data

a. Data Primer adalah sejumlah data atau fakta yang diperoleh secara langsung melalui suatu penelitian lapangan dengan wawancara kepada responden: 1) Informasi dari difabel yg membentuk KUBE; 2) Informasi dari pihak-pihak yang terkait dalam penanganan masalah difabel seperti Dinsosnakertrans, Kabupaten Karanganyar.

b. Data Sekunder adalah data yang dipergunakan sebagai bahan penunjang data primer diperoleh dari buku literatur, majalah, arsip, koran, gambar, dokumentasi hasil penelitian yang sesuai dengan tema penelitian.
4. Teknik Pengumpulan Data

a. Observasi, Wawancara terhadap difabel yang menjadi sasaran kegiatan pemberdayaan melalui Program Kelompok Usaha Bersama (KUBE).

b. Dokumentasi adalah teknik pengumpulan data yang dilakukan dengan mengadakan pencatatanpencatatan atau pengutipan dan pengambilan gambargambar dari dokumen yang ada dilokasi penelitian.

5. Validitas Data

$$
\begin{aligned}
& \text { Peneliti menggunakan } \\
& \text { teknik trianggulasi sumber } \\
& \text { sebagai teknik untuk mengecek } \\
& \text { keabsahan data penelitian. }
\end{aligned}
$$

6. Teknik Analisis Data

Penelitian ini menggunakan mmodel analisis interaktif (Interactive Model Analisis). Tiga komponen tersebut adalah reduksi data, sajian data dan penarikan kesimpulan atau verifikasi. (Miles dan Hubberman (1992:16)

\section{HASIL DAN PEMBAHASAN}

1. Pelaksanaan Program

Pemberdayaan Difabel Melalui

Program KUBE di Desa Suruh,

Kecamatan Tasikmadu,

Kabupaten Karanganyar 
Program pemberdayaan untuk difabel disesuaikan dengan jenis kecacatan dan derajat kecacatan difabel. Adapun jenis pelatihan yang diberikan oleh Dinas Sosial Kabupaten Karanganyar kepada difabel di Desa Suruh, Kecamatan, Tasikmadu, Kabupaten Karanganyar antara lain :

a. Memasak

Jenis keterampilan ini diperuntukkan bagi tuna daksa dan tuna rungu yang berminat pada keterampilan memasak dan mempunyai keinginan untuk membuka usaha dibidang makanan. Jenis keterampilan memasak adalah perempuan, walaupun ada beberapa lakilaki. Program ini dilaksanakan selama kurang lebih 3 bulan di Loka Bina Karya (LBK) Desa Suruh, Kecamatan Tasikmadu, Kabupaten Karanganyar.

b. Menjahit

Jenis keterampilan ini diperuntukkan bagi tuna daksa dan tuna wicara yang berminat pada keterampilan menjahit dan mempunyai keinginan untuk membuka usaha menjahit. Sebagian besar difabel yang mengambil jenis keterampilan menjahit adalah perempuan, walaupun ada beberapa laki-laki.
Program ini dilaksanakan selama kurang lebih 3 bulan di Loka Bina Karya (LBK) Desa Suruh, Kecamatan Tasikmadu, Kabupaten Karanganyar. Mereka diajari cara menjahit dan membuat pola, memotong kain.

c. Perbengkelan atau Montir.

Jenis keterampilan ini diperuntukkan bagi tuna daksa dan tuna wicara yang berminat pada keterampilan dan mempunyai keinginan untuk membuka usaha bengkel motor sendiri. Sebagian besar difabel yang mengambil jenis keterampilan ini adalah laki-laki. Program ini dilaksanakan selama kurang lebih 3 bulan di Loka Bina Karya (LBK).

d. Elektro atau Teknik Audio Video

Jenis keterampilan ini diperuntukkan bagi tuna daksa dan tuna rungu wicara yang berminat pada keterampilan elektro dan mempunyai keinginan untuk membuka usaha perbaikan barang-barang elektronik. Program ini dilaksanakan selama kurang lebih 3 bulan di Loka Bina Karya (LBK).

e. Memijat

Jenis keterampilan ini diperuntukkan bagi tuna netra Page | 153 
yang berminat pada keterampilan memijat dan mempunyai keinginan untuk membuka usaha pemijatan. Program ini dilaksanakan selama kurang lebih 3 bulan di Loka Bina Karya (LBK). Para difabel awalnya kesulitan akan tetapi setelah dicoba beberapa kali akhirnya mereka mulai bisa.

Pengembangan usaha kecil menengah membuka peluang/ kesempatan kerja dalam rangka meningkatkan taraf hidup masyarakat dengan membentuk Kelompok Usaha Bersama (KUBE), dimana 1 kelompok terdiri dari maksimal 5 orang yang memiliki keterampilan yang sama dan bergerak di bidang yang sama. Contoh: penyandang tuna daksa yang memiliki keterampilan elektro, setelah mereka selesai mengikuti pelatihan mereka akan membentuk KUBE elektro, setelah KUBE mereka berhasil, mereka akan membuka bengkel elektro di rumah mereka masingmasing.

Peran Pemerintah Daerah Kabupaten Karanganyar dalam program kewirausahaan ini hanya sebagai pemberi modal dan alatalat kerja saja, sedang monitoring pelaksanaan program kewirausahaan di lapangan diserahkan langsung ke Dinas Sosial. Jadi, misalnya KUBE mengalami masalah yang berkaitan dengan kekurangan modal dan alat-alat kerja, Pemerintah Daerah Kabupaten Karanganyar siap membantunya. Pelatihan yang diberikan tidak semuanya berhasil. Ada beberapa difabel yang kurang terampil dan tidak terampil diakhir pelatihan, sehingga difabel masih membutuhkan bimbingan dan latihan lebih lanjut. Adapun alasan ketidakberhasilan Kelompok Usaha Bersama (KUBE) disebabkan oleh :

a. Derajat kecacatan difabel. Sebagian besar difabel yang tidak terampil ini disebabkan oleh tingginya derajat kecacatan mereka. Contohnya, tuna daksa yang hanya memiliki 1 tangan.

b. Difabel beberapa kali tidak mengikuti pelatihan.

c. Jumlah hari pelatihan yang sangat singkat.

\section{Faktor Pendukung Pelaksanaan KUBE}

a. Pendamping

Pendamping KUBE bertugas:

1. Melakukan kajian dan verifikasi terhadap datadata difabel khususnya yang menjadi sasaran kegiatan.

2. Melakukan identifikasi awal atau tes derajat 
kecacatan (semakin rendah kecacatan akan semakin memudahkan pemberian keterampilan). Tes derajat kecacatan berlaku bagi semua difabel apapun jenis kecacatannya.

Pelaksanaan tes derajat kecacatan ini bekerjasama dengan dokter ahli dari RSU Kabupaten Karanganyar.

3. Memberikan pelatihan atau keterampilanketerampilan kepada difabel sesuai dengan jenis kecacatan dan jenis derajat kecac

4. Memfasilitasi

pelaksanaan pembinaan atau pengembangan Kelompok Usaha Bersama (KUBE) bagi difabel.

b. Pemerintah

Pemerintah memiliki peran dalam mendukung program pemberdayaan difabel. Hal ini terlihat dari kegiatan yang dilakukan mulai dari merehabilitasi, memberikan bantuan sosial kepada kaum difabel dan pemeliharaan kesejahteraan sosial dalam bentuk pemberian pelayanan yang bersifat terus menerus kepada para difabel. c. Peran Masyarakat

Masyarakat dapat berperan dalam memberikan saran, memberikan masukan dan solusi kepada Pemerintah Daerah, supaya pemerintah lebih memperhatikan kaum difabel difabel di daerahnya. Pemberian kesempatan dan perlakuan yang sama bagi difabel dalam segala aspek kehidupan. Masyarakat perlu berpikiran positif terhadap keberadaan difabel di lingkungannya. Selain itu, perlu adanya pemberian lapangan kerja dan usaha bagi kaum difabel agar mereka dapat menyalurkan potensi dan kemampuan yang dimilikinya untuk mensejahterakan kondisi hidupnya dan keluarganya.

\section{Faktor Faktor Penghambat Pelaksanaan KUBE}

a. Hambatan Pada Pola Perilaku Hal ini berkaitan dengan dinamika tingkah laku dalam sikap dan gerak dapat menggambarkan suasana kehidupan perasaan, daya khayal dan cita-cita seseorang.

b. Masalah Pekerjaan dan Ekonomi

Kecacatan merupakan penyebab timbulnya kesukaran untuk melakukan Page | 155 
pekerjaan yang umunya dilakukan oleh orang-orang normal.

c. Masalah Sosial

Masalah Sosial yakni
dikarenakan
mendapatkan pekerjaan atau kehilangan pekerjaan, maka mata pencahariannyapun hilang. Hal ini membawa kegoncangan fungsional khsusnya kepada seseorang difabel yang tadinya berkedudukan sebagai pencari nafkah dalam keluarga karena sekarang tidak dapat melakukan tugasnya lagi.

d. Masalah Psikologis

Yaitu kesukaran-kesukaran yang dihadapi oleh difabel dalam ekonomi, pekerjaan, keluarga dan hubungan sosial dengan masyarakat seringkali menjadi demikian berat, sehingga menimbulkan gejala ganguan kejiwaan yang dapat mengganggu kesehatan jiwa difabel. Rasa minder kerap kali mendera para difabel ketika harus berinteraksi dengan masyarakat.

\section{Dampak}

Program

Pemberdayaan Difabel Melalui Program Kelompok Usaha Bersama (KUBE) di Desa Suruh, Kecamatan Tasikmadu, Kabupaten Karanganyar a. Dampak Psikologis

Program Kelompok Usaha Bersama sangat membantu untuk memberikan semangat dan motivasi kepada difabel sehingga mereka tidak lagi merasa hina akan keberadaannya. Bimbingan selain diberikan oleh Dinas Sosial juga dilakukan oleh difabel lama yang juga merupakan pengurus (ada paguyuban difabel Kabupaten Karanganyar).

b. Dampak Aksesibilitas

Pemberian alat bantu untuk memudahkan difabel dalam hal mobilitas seperti kursi roda, tongkat tuna netra, dan kruk. Selain itu, juga dilakukan advokasi tentang aksesibilitas difabel tentang sarana umum yang kurang menunjang bagi difabel.

c. Dampak Ekonomi

Dalam hal ini peran penguatan potensi diri difabel, dengan adanya pelatihan atau keterampilan bagi difabel yang didasarkan pada jenis kecacatannya seperti keterampilan menjahit, memasak, teknik elektro audio, perbengkelan, memijat dan lain-lain. Pelatihan atau keterampilan tersebut banyak memberikan dampak positif bagi para 
difabel. Difabel lebih mandiri dan tidak selalu bergantung pada bantuan orang lain, sehingga difabel dapat meningkatkan kesejahteraan hidup dirinya dan keluarganya.

\section{KESIMPULAN}

dalam $\begin{array}{cr}\text { Pemberdayaan } & \text { difabel } \\ \text { upaya peningkatan }\end{array}$ kesejahteraan sosial melalui program Kelompok Usaha Bersama (KUBE) di Desa Suruh, Kecamatan Tasikmadu, Kabupaten Karanganyar bersifat menyeluruh meliputi pemberdayaan yg bersifat mental, fisik, maupun kemampuan sosial difabel yaitu dengan memberikan pelatihan dan bantuan alat-alat kerja yang dapat menunjang difabel untuk mengembangkan keterampilan.

Pemberdayaan $\begin{array}{r}\text { difabel } \\ \text { upaya }\end{array}$ peningkatan
kesejahteraan sosial di Desa Suruh,
Kecamatan Tasikmadu, Kabupaten
Karanganyar tidak terlepas dari peran
pendampingan dan peran penguatan
potensi diri difabel. Pendamping
membantu dalam membantu
memberikan
Penguatan potensi diri penting untuk mengetahui potensi diri dari masingmasing difabel.

\section{Pemberdayaan difabel}

melalui program Kelompok Usaha Bersama (KUBE) bertujuan untuk memberdayakan difabel yang mana dilakukan melalui berbagai macam kegiatan mulai dari training keterampilan dan kewirausahaan, serta pelatihan keterampilan menjahit yang diperuntukkan bagi difabel tuna daksa dan tuna rungu wicara.. selain memberikan pelatihan dan pendampingan strategi, juga dengan memberikan modal dan peralatan bagi difabel yang mahir dan ingin membuka usaha sendiri, sehingga mereka bisa hidup mandiri dri segi ekonomi, sehingga bisa memenuhi kebutuhan ekonominya sendiri maupun kebutuhan ekonomi keluarganya. Disamping itu kemampuan psikologi difabel dapat menjadi motor penggerak agar difabel tetap bisa eksis dan survive, dan mampu mengangkat moral difabel maupun kemampuan sosial difabel yaitu kemampuan bersosialisasi difabel dengan masyarakat sekitarnya.

\section{a. IMPLIKASI EMPIRIS}

Beberapa program pemberdayaan ditawarkan kepada difabel sesuai dengan minat, jenis kecacatan dan derajat kecacatan difabel sehingga difabel bisa mandiri. Akan tetapi pendamping hanya bisa memberikan pemberdayaan kepada difabel dengan derajat kecacatan tinggi. Difabel yang tidak berhasil dalam proses pemberdayaan belum ada solusi atau bentuk pemberdayaan lain yang lebih tepat sehingga mereka juga bisa mandiri. 


\begin{abstract}
Dalam penelitian ini penulis belum mendapatkan informasi mengenai cara berinteraksi antar difabel yang berbeda jenis kecacatan misalnya tuna netra dengan tuna rungu wicara atau tuna daksa dengan tuna rungu wicara. Selain itu penulis juga belum mengetahui tingkat kemandirian difabel lain yang tidak mengikuti program pemberdayaan melalui Kelompok Usaha Bersama (KUBE).
\end{abstract}

\section{b. IMPLIKASI PRAKTIS}

Penelitian ini menggunakan teori aksi yang tergabung dalam paradigma definisi sosial yang menekankan pada tindakan sosial. Dalam teori aksi ini aktor mengejar tujuan dalam situasi dimana normanorma mengarahkan dalam memilih alternatif cara dan alat untuk mencapai tujuan. Jika dipandang dengan menggunakan teori aksi tersebut disini difabel adalah sebagai aktor yang memburu suatu tujuan yaitu bertujuan untuk memberdayakan difabel. Dalam memburu tujuannya tersebut pendamping mempunyai alternatif cara atau alat untuk sampai kepada tujuannya tersebut. Cara atau alat tersebut diimplementasikan dalam program-program yang dijalankan dalam rangka memberdayakan difabel. Sedangkan cara atau alat untuk mencapai tujuan implementasikan dalam programprogram yang dijalankan dalam rangka memberdayakan difabel.

\section{c. IMPLIKASI METODOLOGIS}

Penelitian ini merupakan jenis penelitian deskriptif kualitatif dimana penelitian ini berusaha untuk memaparkan tentang pemberdayaan difabel dalam upaya peningkatan kesejahteraan sosial melalui Program Kelompok Usaha Bersama (KUBE) di Desa Suruh, Kecamatan Tasikmadu, Kabupaten Karanganyar. Pengambilan sampel menggunakan teknik purposive sampling sehingga sampel dipilih berdasarkan pertimbanganpertimbangan bahwa sampelsampel tersebut dapat mewakili apa yang dimaksudkan dalam tujuan penelitian. Teknik analisa dilakukan dengan teknik analisis komparatif yaitu dengan jalan melakukan pembandingan antara indikator keberdayaan dengan pemberdayaan yang telah dilakukan, reduksi data, sajian data dan penarikan kesimpulan dilakukan secara terus menerus selama proses penelitian masih berlangsung.

\section{d. IMPLIKASI KEBIJAKAN}

Bagi pemerintah agar dijadikan masukan dalam hal penanganan masalah sosial terutama dalam hal pemberdayaan difabel. Oleh karena selama ini Page | 158 
pemerintah kurang memperhatikan kaum difabel yang juga merupakan warga negara. Meskipun sudah ada Undang-Undang yang mengatur hal tersebut, tetapi implementasi dari Undang-Undang tersebut masih sangat jauh dari yang seharusnya. Dalam hal aksesibilitas saja difabel masih mengalami kekerasan struktural karena banyak sekali fasilitas umum seperti gedung pemerintahan yang bertingkat, selain itu sarana dan prasarana lainnya seperti rumah sakit, sekolah, pasar dan lain sebagainya banyak yang tidak dapat diakses oleh difabel. Disamping itu, bagi Pemerintah Daerah, agar wacana dan kajian dari pemberdayaan yang telah dilakukan terhadap difabel di Desa Suruh, Kecamatan Tasikmadu, Kabupaten Karanganyar dapat dijadikan bahan pertimbangan untuk kembali melakukan pemberdayaan karena difabel di Desa Suruh, Kecamatan Tasikmadu, Kabupaten Karanganyar masih memerlukan banyak sekali pendampingan.

\section{DAFTAR PUSTAKA}

Demartoto, 2005, Menyibak Sensitivitas Gender dalam Keluarga Difabel Ed. 1,
Surakarta: Sebelas Maret University Press.

Departemen Sosial Republik Indonesia (DepSos RI). (1996), Pola Dasar Pembangunan, Bidang Kesejahteraan Sosial. Jakarta: DepSos RI.

Ife, Jim, 1995, Community Development Creating Community Alternatives Vision, Analysis and Practice, Australian, Longman.

Kartasasmita, Ginanjar, 1993, Kebijaksanaan dan Strategi Pengentasan Kemiskinan, Malang, Unibraw Fakultas Ilmu Administrasi.

Miles, Matthew dan Huberman, Michael A, 1992, Data Kualitatif, Jakarta : UI Press

Soeharto, Edi, 2004, Peran Negara dalam Pembangunan Sosial, Isue-isue Tematik Pembangunan Sosial: Balatbangsos, Depsos RI: Jakarta

Sulistiati, 2004, Pembangunan Sosial dan Pemberdayaan Sosial. Isue-isue Tematik Pembangunan Sosial: Balatbangsos, Depsos RI: Jakarta

Suparlan, Dr. Parsudi, 1984, Kemiskinan Di Perkotaan, Bacaan Untuk Antropologi Perkotaan, Jakarta : Sinar Harapan dan Yayasan Obor Indonesia. 
Zastrow, 1989, Understanding

Human Behavior And The

Social Environment, Chicago :

Nelson-Hall Publishers.

Peraturan Undang-Undang

Undang-Undang Dasar RI 1945

Undang-Undang No 4 Tahun 1997

tentang Penyandang Cacat

Undang-Undang No. 11 Tahun 2009

tentang Kesejahteraan Sosial 